\title{
Superior Photocurrent of Quantum Dot Sensitized Solar Cells Based on PbS : In/CdS Quantum Dots
}

\author{
Zongbo Huang and Xiaoping Zou \\ Research Center for Sensor Technology, Beijing Key Laboratory for Sensor, Ministry of Education Key Laboratory for \\ Modern Measurement and Control Technology, School of Applied Sciences, Beijing information Science and Technology University, \\ Jianxiangqiao Campus, Beijing 100101, China \\ Correspondence should be addressed to Xiaoping Zou; xpzou2005@gmail.com
}

Received 6 May 2014; Revised 17 July 2014; Accepted 25 July 2014

Academic Editor: Hsin-Ying Lee

Copyright (C) 2015 Z. Huang and X. Zou. This is an open access article distributed under the Creative Commons Attribution License, which permits unrestricted use, distribution, and reproduction in any medium, provided the original work is properly cited.

\begin{abstract}
$\mathrm{PbS}$ : In and CdS quantum dots (QDs) are sequentially assembled onto a nanocrystalline $\mathrm{TiO}_{2}$ film to prepare a $\mathrm{PbS}: \mathrm{In} / \mathrm{CdS}$ cosensitized photoelectrode for QD sensitized solar cells (QDSCs). The results show that PbS: In/CdS QDs have exhibited a significant effect in the light harvest and performance of the QDSC. In the cascade structure of the electrode, the reorganization of energy levels between $\mathrm{PbS}$ and $\mathrm{TiO}_{2}$ forms a stepwise structure of band-edge levels which is advantageous to the electron injection into $\mathrm{TiO}_{2}$. Energy conversion efficiency of $2.3 \%$ is achieved with the doped electrode, under the illumination of one sun (AM1.5, $100 \mathrm{~mW} \mathrm{~cm}^{2}$ ). Besides, a remarkable short circuit current density (up to $23 \mathrm{~mA} \cdot \mathrm{cm}^{-2}$ ) is achieved in the resulting $\mathrm{PbS}: \mathrm{In} / \mathrm{CdS}$ quantum dot sensitized solar cell, and the related mechanism is discussed.
\end{abstract}

\section{Introduction}

One of the current challenges for high performance sensitized solar cells is the limited light absorption range from the visible to the near-infrared (NIR) region for the solar spectrum [1]. Generally, molecular dyes can only absorb light photons within a more or less broadband corresponding to their molecular transitions; thus the absorption region of dye sensitized solar cells (DSCs) is limited [2]. On the other hand, semiconductor materials can absorb all photons with energies higher than their band gap, $E_{g}$. The quantum dot sensitized solar cells (QDSCs) are attracting increasing attention as they show promising potential for the development of next generation solar cells with high photocurrent [3-5].

Recently, various quantum dots (QDs), such as CdS, $\mathrm{CdSe}, \mathrm{PbS}, \mathrm{PbSe}$, and InP, have been attempted to fabricate QDSCs [6-10]. PbS $\left(E_{g}=0.41 \mathrm{eV}\right)$ [11], specifically, has attracted increasing interest in sensitizers for achieving superior photocurrent solar cells. Recent work by Zhou et al. has demonstrated a high photocurrent density $\left(J_{\mathrm{SC}}\right.$, nearly $20 \mathrm{~mA} \cdot \mathrm{cm}^{-2}$ ) in the PbS/CdS cosensitized solar cells [12]. However, compared to that of $\mathrm{TiO}_{2}$, the conduction band
(CB) of PbS is located at lower energy [13]. The situation is not conducive to electronic transmission from $\mathrm{PbS}$ to $\mathrm{TiO}_{2}$. Thus, optimization of the structure for photoanode is highly required to improve the electron injection in PbS QDSCs [14].

High performance deep red and NIR emitters are much needed for developing desirable probes for in vivo diagnostics and optical devices application [15-17]. Synthesis of doped semiconductor nanocrystal QDs [18-20] has recently become an active subject in the field of nanomaterials because of their unique optical, electronic, and physical properties [21]. Various advantages have been achieved by doping with optically active transition metal ions (such as $\mathrm{Cu}, \mathrm{In}, \mathrm{Mn}$, and $\mathrm{Mg}$ ) [22, 23] because the electrical and optical properties of QDs could be effectively improved. In addition, the photophysical properties of semiconductor nanocrystals could also be adjusted by different types and concentrations of dopants [24]. The dopant creates electronic states in the midgap region of the QD, thus altering the charge separation and recombination dynamics. Currently, other efforts to design In-doped ZnSe, Mn-doped ZnSe, and In-doped-InP QDs have brought a bright perspective for developing highly efficient and colortunable emitters in the red and NIR window $[19,25,26]$. 


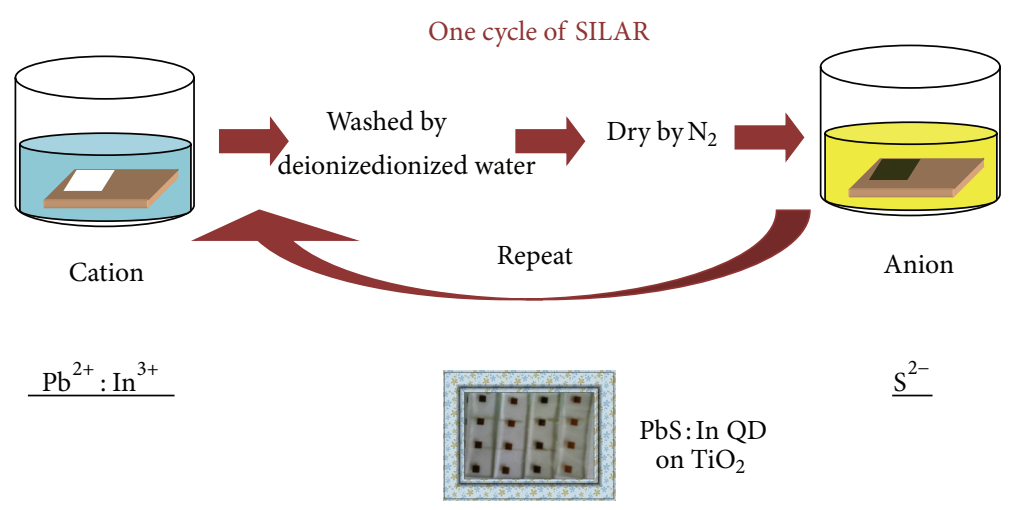

FIgURE 1: Deposition process of In-doped-PbS QDs on mesoporous $\mathrm{TiO}_{2}$ nanostructure using successive ionic layer adsorption and reaction (SILAR) method.

In this work, we have fabricated a photoanode of $\mathrm{PbS}:$ In and CdS QDs deposited by the successive ionic layer adsorption and reaction (SILAR) [27]. Improvement in the QDSC performance has been observed. The photocurrent density up to $23 \mathrm{~mA} \cdot \mathrm{cm}^{-2}$ has been achieved in the $\mathrm{PbS}:$ In semiconductor photoanode. The power conversion efficiency of $2.3 \%$ is mainly due to the extremely high $J_{\mathrm{SC}}$. Furthermore, many experiments have been performed to well demonstrate the material structures and solar cell performance.

\section{Experimental}

2.1. Fabrication of $\mathrm{PbS}: \mathrm{In} / \mathrm{CdS}$ Electrode. The fabrication methods are based on our previous study for $\mathrm{Cu}$-doped $\mathrm{PbS}$ [28]. In a typical experiment, the $\mathrm{TiO}_{2}$ electrode was prepared by the screen printing with an average size of $25 \mathrm{~nm} \mathrm{TiO}_{2}$ paste onto the fluorine-doped tin oxide (FTO) glass (thickness: $2.2 \mathrm{~mm}$, Pilkington, $14 \Omega$ /square). The asprepared electrodes were annealed at $450^{\circ} \mathrm{C}$ for $30 \mathrm{~min}$. Corresponding concentrations $(1: 1,1: 5,1: 10$, and $1: 20)$ of the $\mathrm{InCl}_{3}$ were mixed with $\mathrm{Pb}\left(\mathrm{NO}_{3}\right)_{2}(0.1 \mathrm{M})$ in an ethanol and deionized water $(1: 1)$ mixed solution as cation source, respectively. $\mathrm{Na}_{2} \mathrm{~S}(0.1 \mathrm{M})$ in methanol was used as anion source. The SILAR method was used to sensitize the $\mathrm{TiO}_{2}$ nanoparticles with $\mathrm{PbS}$ : In QDs as shown in Figure 1. Firstly, $\mathrm{TiO}_{2}$ electrodes were dipped in cation source for $1 \mathrm{~min}$, followed by dipping in anion source for $1 \mathrm{~min}$. After each dipping cycle, the electrode was rinsed with corresponding solvent and drying. In the process, the $\mathrm{In}^{3+}$ ions were achieved in the $\mathrm{PbS}$ film. To prevent $\mathrm{PbS}$ : In electrode from the corrosion by polysulfide solution electrolyte [29], CdS layer was deposited on $\mathrm{TiO}_{2}$ by using $\mathrm{Cd}\left(\mathrm{NO}_{3}\right)_{2}(0.1 \mathrm{M})$ aqueous ethanol solution and $\mathrm{Na}_{2} \mathrm{~S}(0.1 \mathrm{M})$ methanol solutions [30].

2.2. Preparation of QDSCs. All the working electrodes and Pt-coated counterelectrodes were finally assembled by using $60 \mu \mathrm{m}$ thick sealing materials (SX-1170-60, Solaronix SA). A mixed methanol and deionized water solution $(1: 1)$ of $\mathrm{Na}_{2} \mathrm{~S}$ $(0.5 \mathrm{M}), \mathrm{S}(2 \mathrm{M})$, and $\mathrm{KCl}(0.2 \mathrm{M})$ was used as the liquid electrolyte [31]. Solar cell performance was evaluated at one sun illumination.

\section{Results and Discussion}

Figure 2(a) shows scanning electron micrograph (SEM) of the bare $\mathrm{TiO}_{2}$ electrode, while Figure 2(b) shows SEM image of the $\mathrm{TiO}_{2}$ electrode deposited by $\mathrm{PbS}$ : In. Compared with bare $\mathrm{TiO}_{2}$ films, the dimension of QD sensitized $\mathrm{TiO}_{2}$ nanoparticles increases slightly and the porosity decreases at the same time. The $\mathrm{Pb}$, In, and $\mathrm{S}$ peaks are clearly observed in the EDS spectrum of the electrode, as shown in the inset of Figure 2(b). Furthermore, Figure 2(c) suggests that the $\mathrm{TiO}_{2}$ films were deposited by $\mathrm{PbS}$ : In with a thickness of $10 \mu \mathrm{m}$. The result confirms that $\mathrm{PbS}$ : In QDs are successfully assembled on the surface of the $\mathrm{TiO}_{2}$ film via the deposition process.

Figure 3(a) shows a high-resolution transmission electron microscopy (HRTEM) image of the $\mathrm{TiO}_{2} / \mathrm{PbS}: \mathrm{In}$ $(\mathrm{Pb}: \mathrm{In}=10: 1)$ electrode, suggesting that the surface of the $\mathrm{TiO}_{2}$ particles has been coated with QDs (gray dots). HRTEM image of the $\mathrm{TiO}_{2} / \mathrm{PbS}$ : In electrode as shown in Figure 3(b) demonstrated fine crystallites with various orientations and lattice spacing around the $\mathrm{TiO}_{2}$ crystallite. According to the (101) plane of $\mathrm{TiO}_{2}$ (JCPDS 21-1272), the lattice spacing measured for the crystalline plane is $0.356 \mathrm{~nm}$. On the basis of careful measurement and comparison of the lattice parameters in JCPD, the lattice of the crystallites deposition on $\mathrm{TiO}_{2}$ is ascribed to the (220) plane of $\mathrm{PbS}$, without observing independent In phase. These results indicate that PbS: In nanocrystals have been absorbed on the surface of porous $\mathrm{TiO}_{2}$; thus a $\mathrm{TiO}_{2} / \mathrm{PbS}$ : In cascade structure was achieved.

Powder X-ray diffraction (XRD) of the $\mathrm{TiO}_{2}$ electrodes sensitized with PbS:In QDs ( $\mathrm{Pb}: \mathrm{In}=10: 1)$ was performed. Figure 4 shows the XRD patterns of $\mathrm{TiO}_{2} / \mathrm{PbS}$ and $\mathrm{TiO}_{2} / \mathrm{PbS}$ : In films at room temperature (RT) and $200^{\circ} \mathrm{C}$. The typical diffraction peaks of the SILAR deposited $\mathrm{PbS}$ films were located at $32.3^{\circ}, 48.1^{\circ}$, and $62.9^{\circ}$, corresponding to (111), (220), and (222) crystalline planes of cubic phase (galena) of $\mathrm{PbS}$, respectively. The XRD patterns of the In-doped $\mathrm{PbS}$ phase at room temperature were in good agreement with those of undoped $\mathrm{PbS}$ phase at room temperature and $200^{\circ} \mathrm{C}$. However, (220) peak for the cubic phase of $\mathrm{PbS}$ was found to slightly shift from $48.1^{\circ}$ to $47.6^{\circ}$ in the $\mathrm{TiO}_{2} / \mathrm{PbS}$ : In nanoporous films annealed at $200^{\circ} \mathrm{C}$. Thus, In doping could 


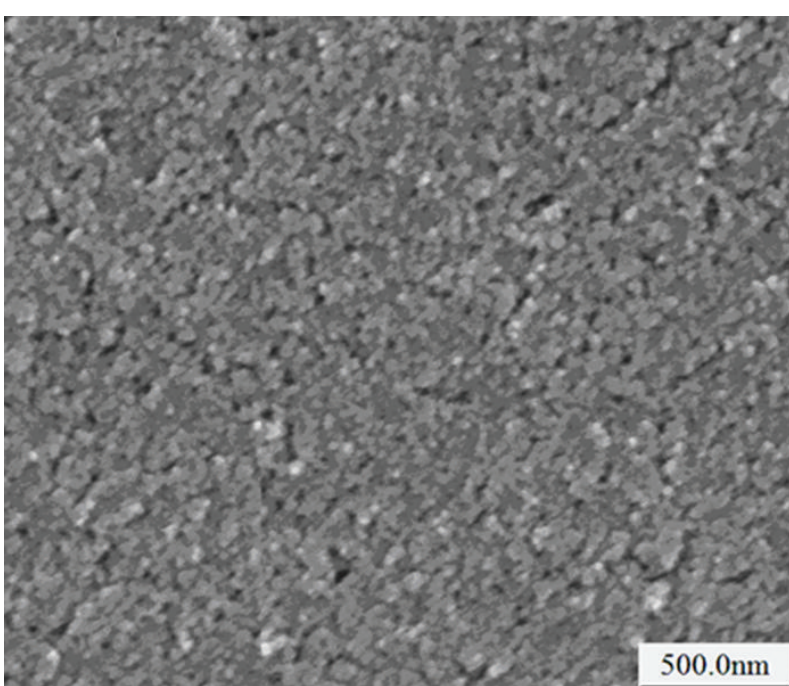

(a)

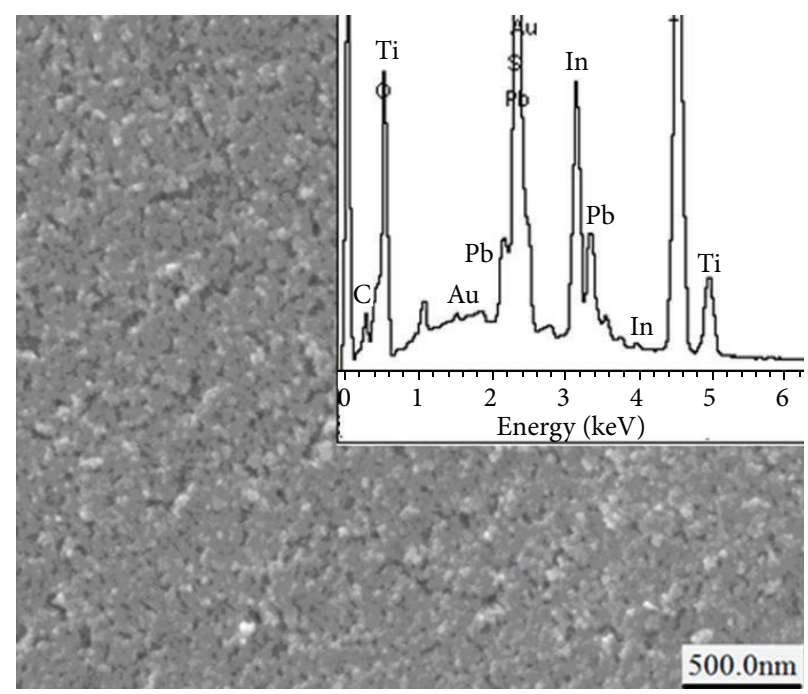

(b)

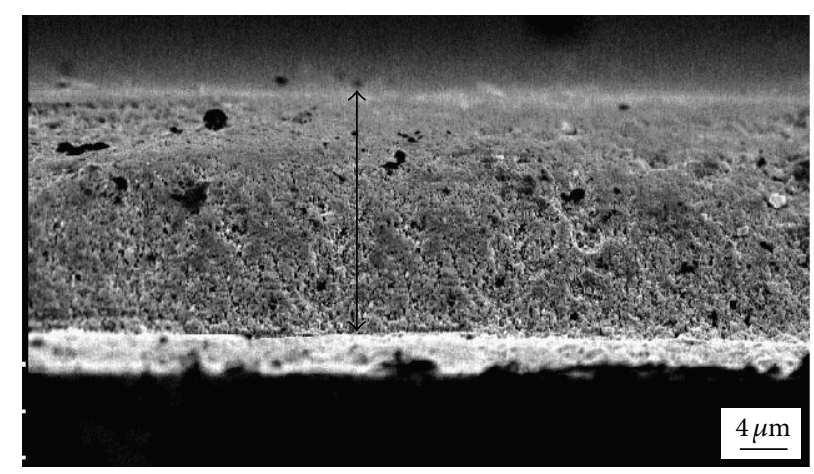

(c)

Figure 2: SEM images of the top view for the nanocrystalline $\mathrm{TiO}_{2}$ film (a) and $\mathrm{TiO}_{2}$ deposited by $\mathrm{PbS}$ : In film (b); the cross-section view of the $\mathrm{TiO}_{2}$ deposited by $\mathrm{PbS}$ : In film (c); the inset in parts (b) shows the corresponding EDS spectra.

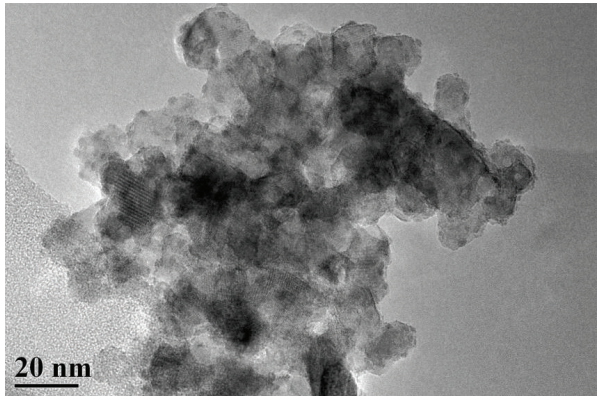

(a)

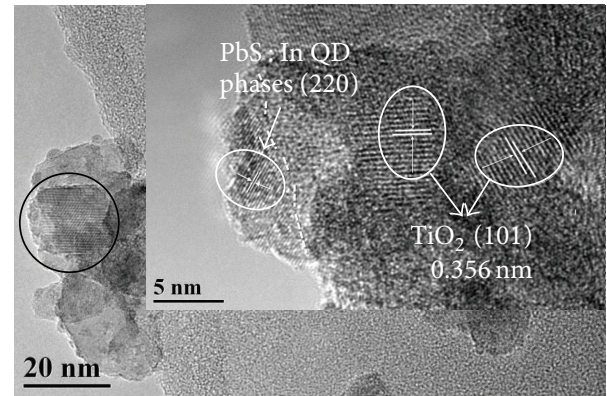

(b)

Figure 3: (a) and (b) are low-magnification HRTEM images of the PbS:In film. The inset in parts (b) shows the corresponding highmagnification HRTEM image.

lead to the change of the crystalline structure of $\mathrm{PbS}$, which indicates the formation of In in the as-prepared samples.

Figure 5(a) shows the UV-vis absorption spectra of $\mathrm{PbS}$ : In QDs look red-shifted compared to the pristine $\mathrm{PbS}$, especially in visible region. Optical band gap of the QDs is estimated from UV-vis absorption spectra using KubelkaMunk equation [32] and Tauc plot [33] (Figure 5(b)). The optical band gap of PbS : In QD increases from $1.0 \mathrm{eV}$ to $1.4 \mathrm{eV}$ as the doping concentration increases from 0 to $1: 1$. However, the threshold for the PbS doped with In (PbS:In = 1:1, 5:1) in the NIR region in inset of Figure 5(a) is moved to shorter wavelength than the pristine $\mathrm{PbS}$, which is consistent with the increase in band gap.

Furthermore, the PbS:In QD adsorbed $\mathrm{TiO}_{2}$ of low binding energy was observed by ultraviolet photoelectron spectroscopy (UPS) spectra. Secondary cut-off is fitted to 
TABLE 1: Parameters of photovoltaic performance of the QDSCs with different concentrations of $\mathrm{PbS}: \mathrm{In}$.

\begin{tabular}{lcccc}
\hline Sample & $J_{\mathrm{SC}} / \mathrm{mA} \mathrm{cm}^{-2}$ & $V_{\mathrm{OC}} / \mathrm{V}$ & $\mathrm{FF}$ & $\eta(\%)$ \\
\hline $\mathrm{Pb}: \mathrm{In}=1: 1$ & 5.07 & 0.39 & 0.36 & 0.71 \\
$\mathrm{~Pb}: \mathrm{In}=5: 1$ & 16.94 & 0.44 & 0.22 & 1.64 \\
$\mathrm{~Pb}: \mathrm{In}=10: 1$ & 19.11 & 0.42 & 0.27 & 2.17 \\
$\mathrm{~Pb}: \mathrm{In}=20: 1$ & 15.31 & 0.41 & 0.22 & 1.38 \\
\hline
\end{tabular}

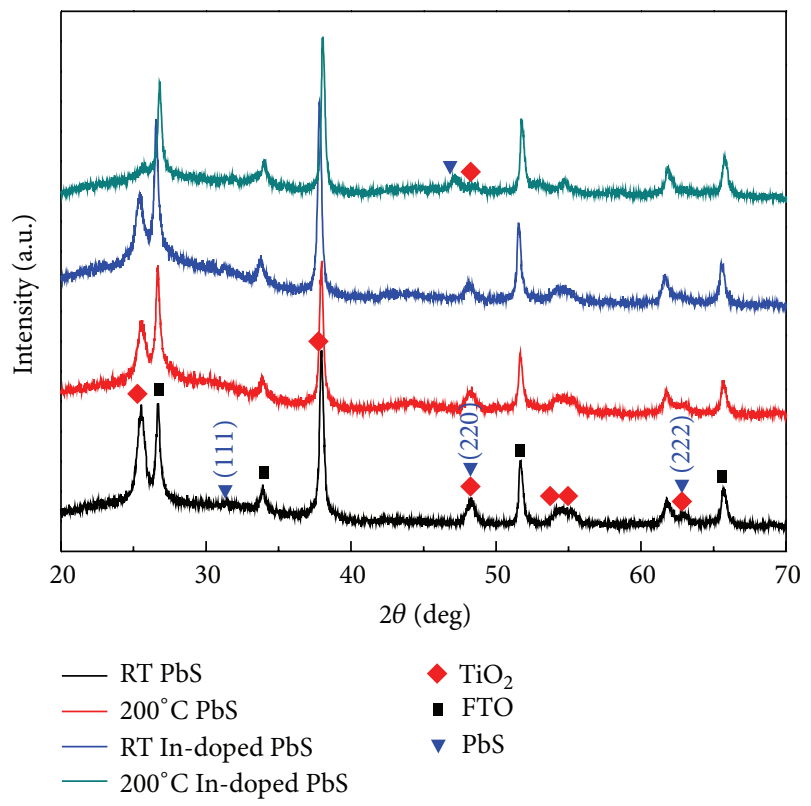

FIgure 4: The XRD patterns of $\mathrm{PbS}$ and $\mathrm{PbS}$ : In films at room temperature and $200^{\circ} \mathrm{C}$.

energy of He I light source $(21.2 \mathrm{eV})$, where measurement of low energy region corresponds to potential energy of valence band maximum (VBM) from the vacuum level, as shown in Figure 5(c). The position of conduction band minimum (CBM) can be calculated based on VBM and optical band gap energy. Band-edge alignment is demonstrated in Figure 5(d), where CBM of the QDs moves upward as the concentration decreases from 0 to $10: 1$ and moves downgrade as the concentration decreases from $10: 1$ to $20: 1$. It is indicated that CBM is slightly altered by In concentration. So it is likely to shape a stepwise structure of between $\mathrm{PbS}$ and $\mathrm{TiO}_{2}$ bandedge levels which is advantageous to the electron injection into $\mathrm{TiO}_{2}$, as shown in Figure 5(e).

The $J-V$ characteristics with different In-doped concentrations for 2 SILAR cycles of PbS:In and 4 SILAR cycles of $\mathrm{CdS}$ solar cell are shown in Figure 6. The short circuit current density $\left(J_{\mathrm{SC}}\right)$, the open circuit voltage $\left(V_{\mathrm{OC}}\right)$, the fill factor $(\mathrm{FF})$, and the power conversion efficiency $(\eta \%)$ are shown in Table 1, respectively. Obviously, the best performance of the doped solar cell is achieved based on the $(\mathrm{Pb}: \mathrm{In})$ concentration ratio $(10: 1)$. An inductively coupled plasma optical emission spectroscopy (ICP-OES) was performed to determine the actual In-doped concentration. The results suggest the concentration was $1.6 \%$ in the $\mathrm{PbS}$ film. Either higher or lower In-doped concentration might damage the performance of QDSCs. The optimal concentration was found to be $10: 1$ to form a cascade structure for the electronic transmission. The implication of experimental data suggested that $V_{\mathrm{OC}}$ enhanced the increase of the doping concentration.

Similarly, the doped system with different SILAR cycles of CdS is completed. The normalized absorption spectra of these electrodes are shown in Figure 7(a). Absorption around $550 \mathrm{~nm}$ was found in the diffusion reflectance absorbance spectra of $\mathrm{PbS}: \mathrm{In} / \mathrm{CdS}$ deposited film, demonstrating enhanced ability for capturing incident photons with the increasing of the CdS layer. The $J-V$ characteristics well correspond to the diffusion reflectance absorbance spectra shown in Figure 7(b). The 6 SILAR cycles of short circuit current density $\left(\sim 23.42 \mathrm{~mA} \cdot \mathrm{cm}^{-2}\right)$ are higher than other cycles. The highest efficiency (2.36\%) is obtained with the 6 SILAR cycles of CdS layer (Table 2). The addition of SILAR cycle of CdS can reduce the recombination and enhancement $\mathrm{V}_{\mathrm{OC}}$ in the cell is observed in Table 2.

For the comparative study, two different types of semiconductor photoanodes were prepared: (i) 2 SILAR cycles of undoped PbS and 6 SILAR cycles of CdS and (ii) 2 SILAR cycles of PbS:In $(\mathrm{Pb}: \operatorname{In}=10: 1)$ and 6 SILAR cycles of CdS. The normalized absorption spectra of these electrodes are shown in Figure 8(a). Absorption around $1200 \mathrm{~nm}$ was observed in the absorption spectra of $\mathrm{PbS}: \mathrm{In} / \mathrm{CdS}$ deposited film, demonstrating enhanced ability for capturing incident photons.

Figure 8(b) shows incident photon-to-electron conversion efficiency (IPCE) spectra of the doped and undoped QDSCs at different incident light wavelengths. Compared to the $\mathrm{PbS} / \mathrm{CdS}$ ones, much more increment in overall photocurrent response, specifically in the NIR region, was found in the $\mathrm{PbS}: \operatorname{In} / \mathrm{CdS}$ electrodes, showing maximum IPCE greater than $70 \%$. Light scattering layer increases further IPCE at longer wavelength (IPCE of $40 \%$ at $800 \mathrm{~nm}$ and $10 \%$ at $1200 \mathrm{~nm}$ ). The broad absorption in the visible and higher photoconversion efficiency highlights the importance of In doping of the metal chalcogenide films. Very recently, the highest short circuit current density with a maximum EQE $(74.6 \%$ at $470 \mathrm{~nm})$ of $\mathrm{PbS}: \mathrm{Hg}$ QD sensitized solar cell was demonstrated to change it [28]. We can refer it to some references [34-39]. It is indicated that short circuit photocurrent density has a stronger relevance with working electrode absorb light range than value of IPCE.

The $J-V$ characteristics of these two QDSCs are presented in Figure 8(c). Surprisingly, $\mathrm{PbS}: \mathrm{In} / \mathrm{CdS}$ films that exhibited a significant increment close to $50 \%$ (from $15.73 \mathrm{~mA} \cdot \mathrm{cm}^{-2}$ to $23.01 \mathrm{~mA} \cdot \mathrm{cm}^{-2}$ ) in the photocurrent are shown in Table 3 , compared to the corresponding undoped films. Similarly, the open circuit voltage was found to dramatically increase from $0.35 \mathrm{~V}$ to $0.39 \mathrm{~V}$ after doping. Although the fill factor still remained at very low level, the increase in the short circuit current and the open circuit voltage with In-doped system leads to the enhancement in the overall power conversion efficiency, suggesting higher efficiency of $2.30 \%$ based on the undoped one $(1.38 \%)$.

The enhanced performance of $\mathrm{PbS}: \mathrm{In} / \mathrm{CdS}$ films is mainly attributed to the CBM and VBM realignment by In 

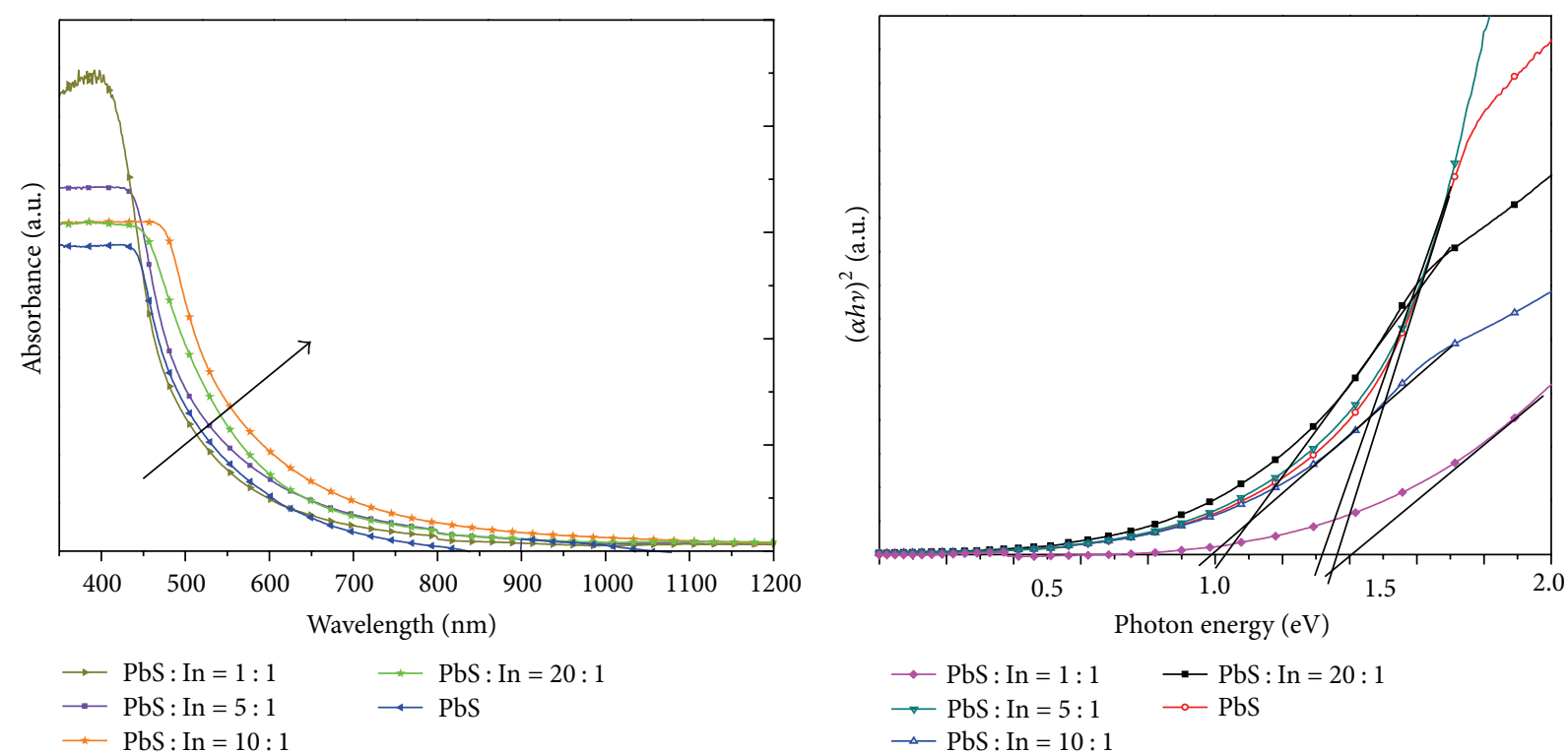

$\longrightarrow$ PbS:In $=1: 1 \quad \longrightarrow$ PbS:In $=20: 1$
$\longrightarrow$ PbS:In $=5: 1$
$\longrightarrow$ PbS:In $=10: 1$

(a)

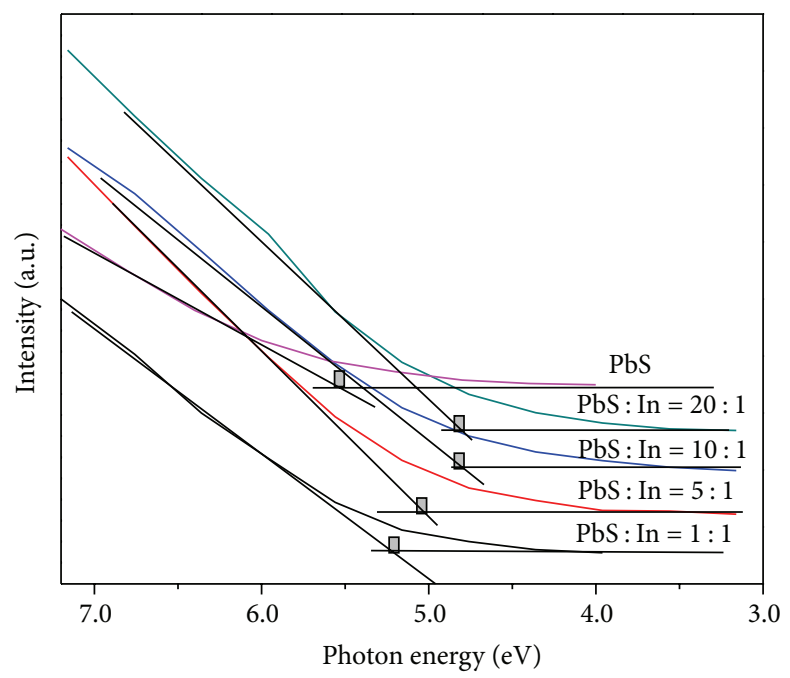

(c)

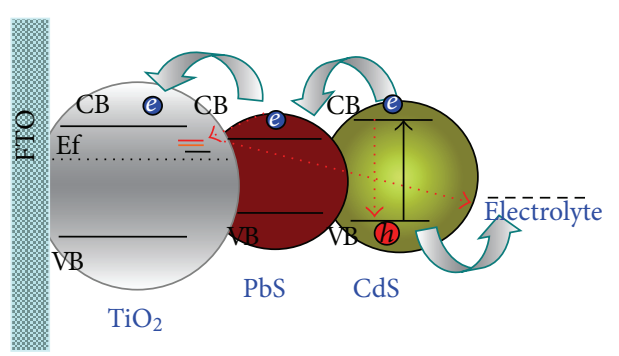

(i)

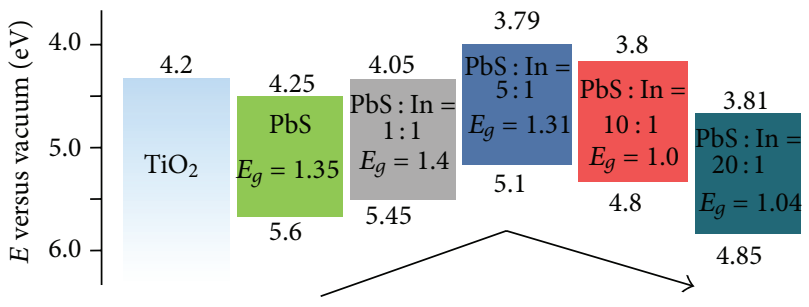

(d)

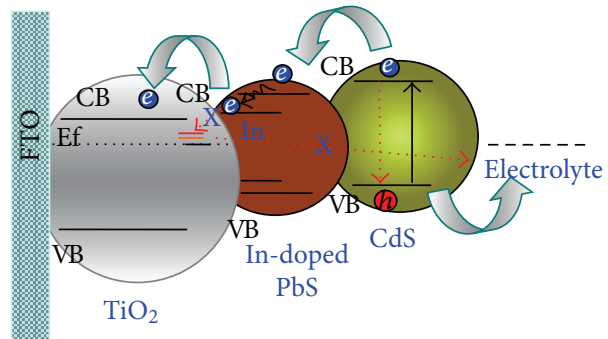

(ii)

(e)

FIgURE 5: (a) UV-vis absorption spectra of PbS: In QD (PbS:In = 0, 1:1, 5:1, 10:1, and $20: 1$ ) adsorbed $\mathrm{TiO}_{2}$ and (b) Tauc plot calculated by using Kubelka-Munk equation from UV-vis absorption; (c) UPS spectra of PbS: In QD (PbS: In = 0, 1:1, 5:1, 10:1, and 20:1) adsorbed TiO 2 and extrapolation of low binding energy region. (d) Band-edge alignment diagram for $\mathrm{PbS}$ and $\mathrm{PbS}$ : In QDs. (e) Schematic illustration of the electron and hole transfer model for undoped PbS/CdS (i) and PbS : In/CdS (ii). 
TABLE 2: Parameters of photovoltaic performance of the QDSCs with different SILAR cycles of CdS.

\begin{tabular}{|c|c|c|c|c|}
\hline Sample & $J_{\mathrm{SC}} / \mathrm{mA} \cdot \mathrm{cm}^{-2}$ & $V_{\mathrm{OC}} / \mathrm{V}$ & $\mathrm{FF}$ & $\eta(\%)$ \\
\hline$(\mathrm{Pb}: \operatorname{In}=10: 1) \mathrm{PbS}: \operatorname{In}(2) / \mathrm{CdS}(4)$ & 19.41 & 0.42 & 0.22 & 1.95 \\
\hline$(\mathrm{Pb}: \operatorname{In}=10: 1) \mathrm{PbS}: \operatorname{In}(2) / \mathrm{CdS}(6)$ & 23.42 & 0.44 & 0.23 & 2.36 \\
\hline$(\mathrm{Pb}: \operatorname{In}=10: 1) \mathrm{PbS}: \operatorname{In}(2) / \mathrm{CdS}(8)$ & 20.21 & 0.46 & 0.23 & 2.18 \\
\hline
\end{tabular}

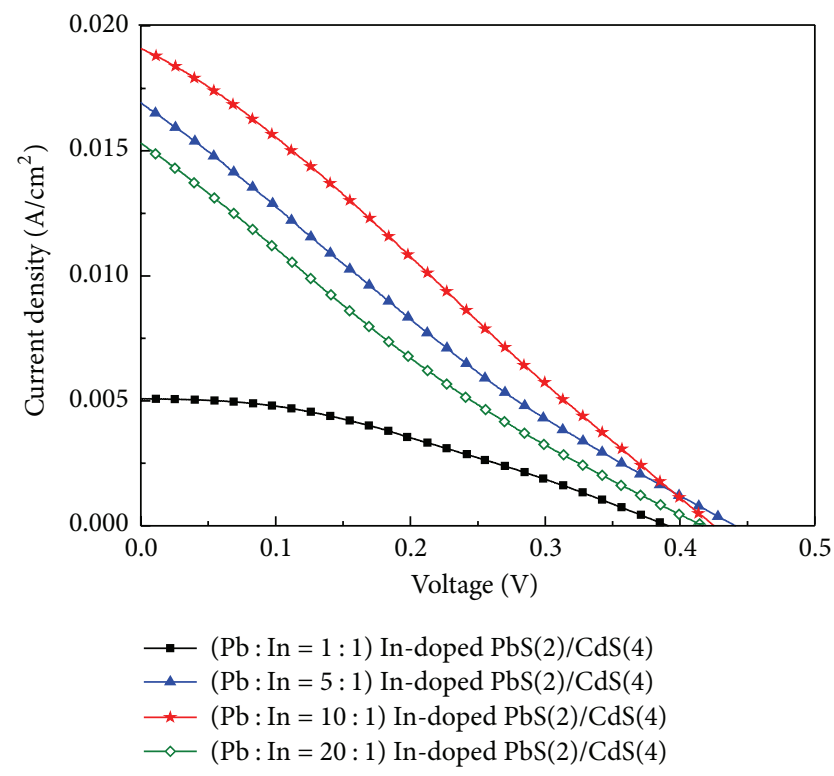

FIGURE 6: The $J-V$ characteristics with different concentrations of PbS:In sensitized solar cell: $\mathrm{Pb}: \mathrm{In}=1: 1(\mathbf{\square}), \mathrm{Pb}: \mathrm{In}=5: 1(\boldsymbol{\Delta})$, $\mathrm{Pb}: \mathrm{In}=10: 1(\star)$, and $\mathrm{Pb}: \operatorname{In}=20: 1(\diamond)$.

TABLE 3: Parameters of photovoltaic performance of PbS/CdS and PbS : In/CdS QDSCs.

\begin{tabular}{lcccc}
\hline Sample & $J_{\mathrm{SC}} / \mathrm{mA} \cdot \mathrm{cm}^{-2}$ & $V_{\mathrm{OC}} / \mathrm{V}$ & $\mathrm{FF}$ & $\eta(\%)$ \\
\hline $\mathrm{PbS} / \mathrm{CdS}$ & 15.73 & 0.35 & 0.25 & 1.38 \\
$\mathrm{PbS}: \mathrm{In} / \mathrm{CdS}$ & 23.01 & 0.40 & 0.26 & 2.30 \\
\hline
\end{tabular}

doping, which effectively separate the electrons and holes into QD layers. The cascade structure of $\mathrm{TiO}_{2} / \mathrm{PbS}: \mathrm{In} / \mathrm{CdS}$ is similar to that of $\mathrm{Hg}$ - and $\mathrm{Cu}$-doped system [26, 28], as shown in Figure 5(e)(ii). The transmission path is advantageous to the accumulation of more electrons for increasing photovoltage and short circuit current density of QDSCs. Besides, the energy gap of $\mathrm{PbS}$ is maintained, which benefits multiexciton generation.

Through the impedance measurement we can also confirm the above conclusions. Impedance measurement of the QDSCs based on $\mathrm{TiO}_{2} / \mathrm{PbS} / \mathrm{CdS}$ and $\mathrm{TiO}_{2} / \mathrm{PbS}: \mathrm{In} / \mathrm{CdS}$ photoelectrodes is presented in Figure 8(d). Equivalent circuit in the insert has been suggested in another sentence [37-39] to model the impedance spectrum (IS) of QDSCs. According to the equivalent circuit, two semicircles should be obtained in each IS. The recombination resistance $\left(R_{\text {rec }}\right.$, a chargetransfer resistance related to recombination of electrons at the $\mathrm{TiO}_{2}$ /electrolyte interface) of the doped system is much

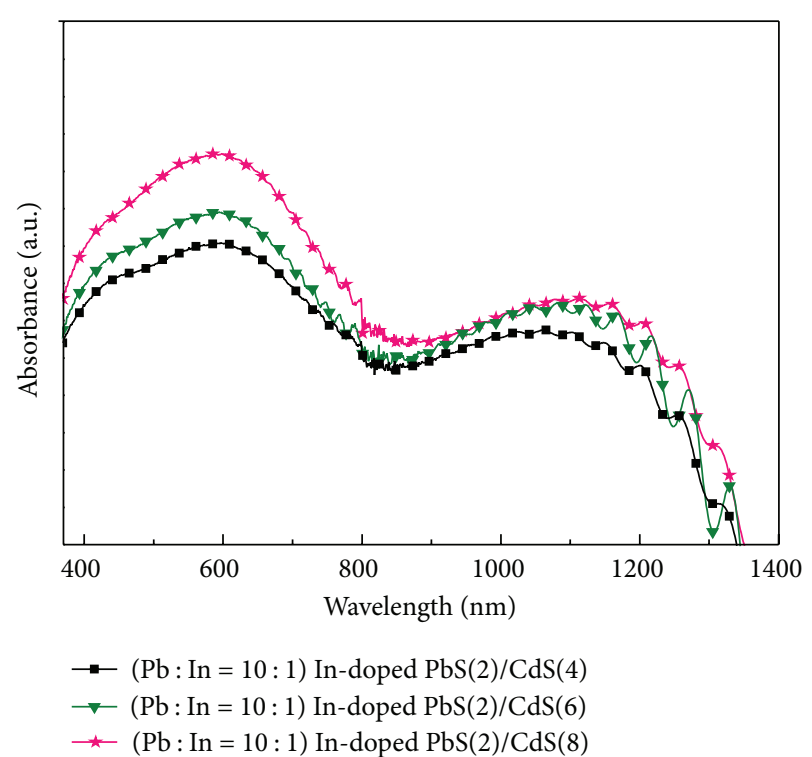

(a)

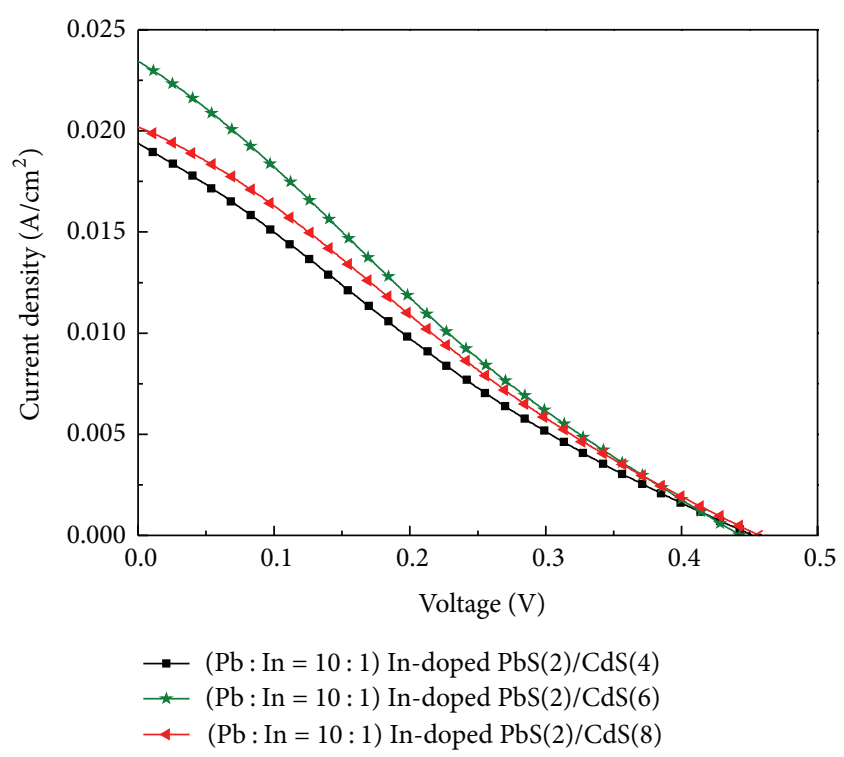

(b)

FIgURE 7: The diffusion reflectance absorbance spectra (a) and J-V characteristics (b) with different working electrodes based on SILAR cycles of CdS layer: $\operatorname{CdS}(4)(\boldsymbol{\nabla}), \operatorname{CdS}(6)(\boldsymbol{\nabla})$, and $\operatorname{CdS}(8)(\star)$.

higher than undoped system. Besides, $R_{\text {rec }}$ is inversely proportional to both the recombination rate and the density of electrons in $\mathrm{TiO}_{2}$, which could partially account for the longer electron lifetime and higher photocurrent in $\mathrm{TiO}_{2} /$ $\mathrm{PbS}: \mathrm{In} / \mathrm{CdS}$ photoelectrode. 


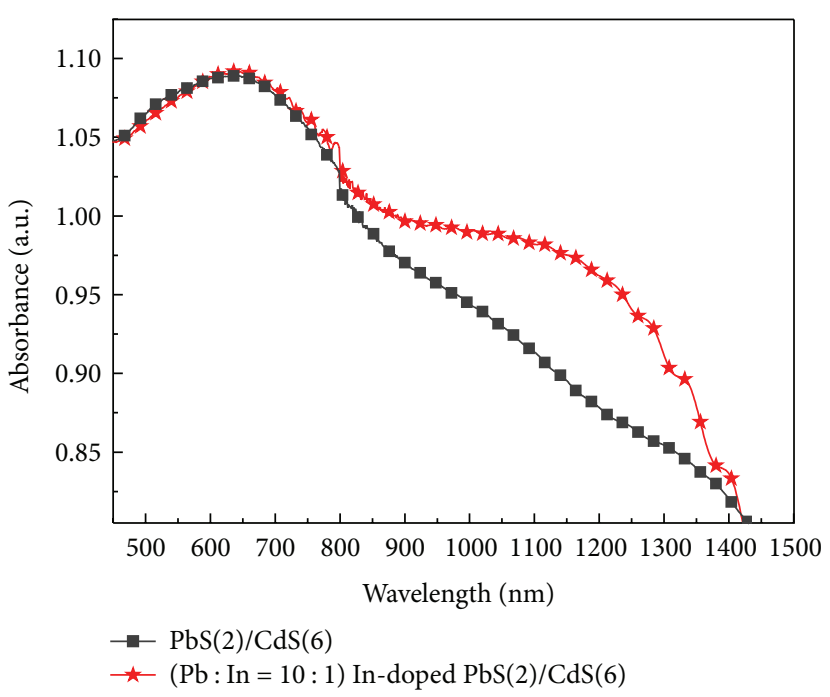

(a)

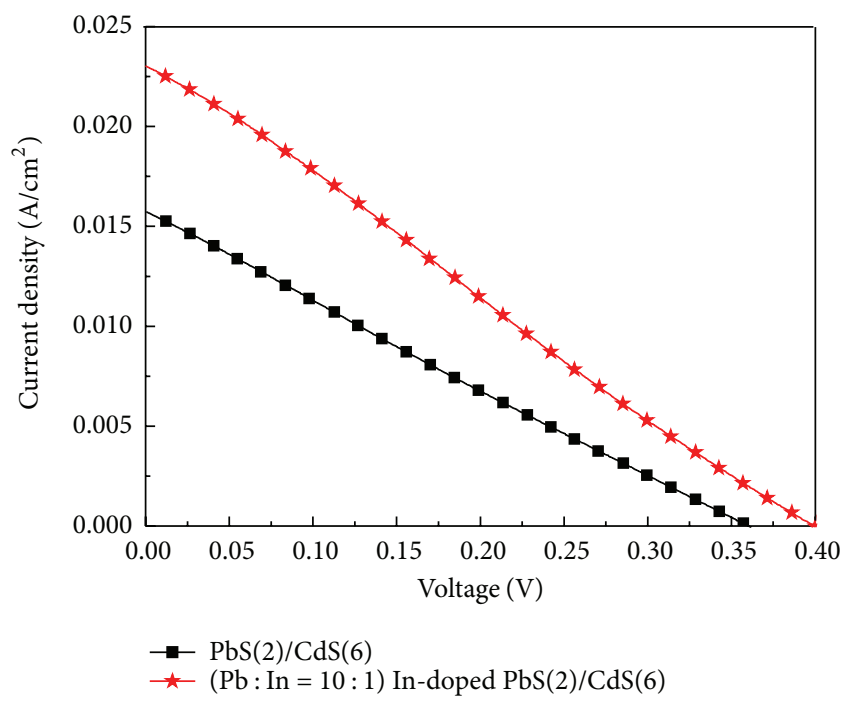

(c)

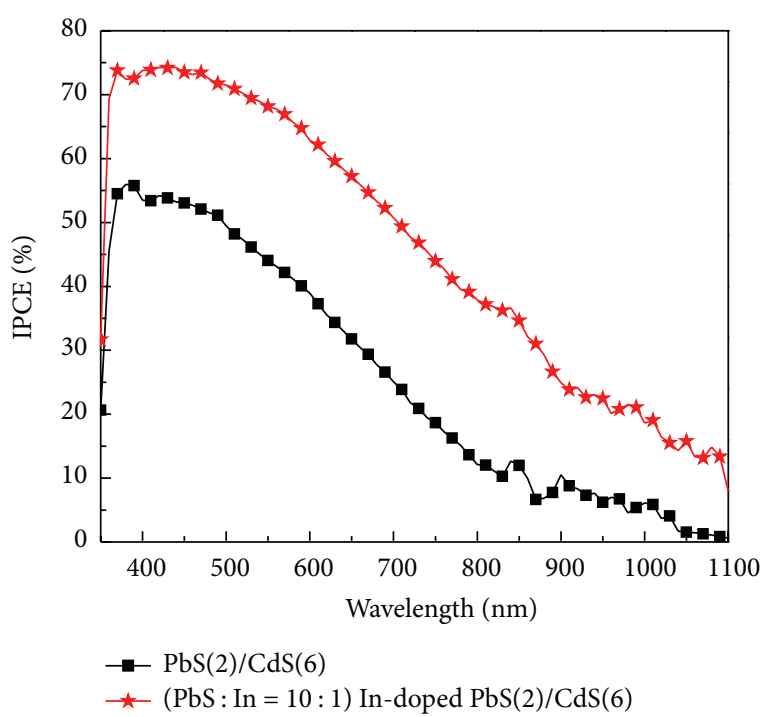

(b)

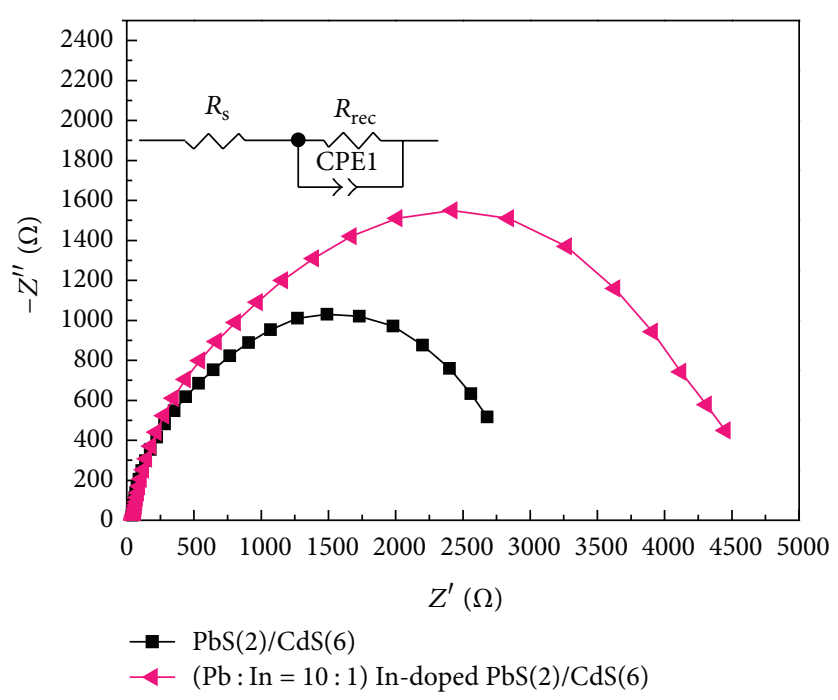

(d)

FIGURE 8: (a) Diffusion reflectance absorbance spectra of semiconductor films deposited on mesoporous $\mathrm{TiO}_{2}$ films: $\mathrm{PbS} / \mathrm{CdS}$ ( $\mathbf{\square}$ ),

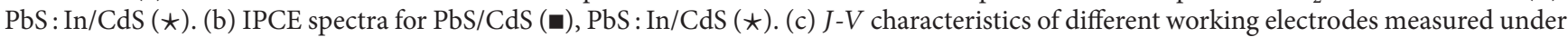
AM 1.5 global filter of $100 \mathrm{~mW} \mathrm{~cm}{ }^{-2}$ sunlight: undoped PbS/CdS (®), PbS : In/CdS ( $)$. (d) Impedance measurement of QDSCs: undoped $\mathrm{PbS} / \mathrm{CdS}(\boldsymbol{\square}), \mathrm{PbS}: \mathrm{In} / \mathrm{CdS}(\boldsymbol{\Delta})$ at an applied negative bias, $V_{\mathrm{appl}}=-0.4 \mathrm{~V}$, under dark conditions. The working electrodes areas were both at $0.09 \mathrm{~cm}^{2}$.

However, there are still several factors limiting the power conversion efficiency in QDSCs. (i) The Pt counterelectrode has poorer performance in the improvement of the fill factor for the QDSCs, comparing to other counterelectrodes [39, 40]. (ii) Good photoanode and bad counterelectrode do not match each other, against electrolytic oxidation reduction [28]. (iii) Difficulties have been also found in the SILAR method for controlling the QD size and size distribution, optimizing QD sensitized electrode structure, high coverage, and band alignment of QDs, thus slowing electron injection into $\mathrm{TiO}_{2}$ and hole transfer into sulfide redox couples. The high charge recombination is severe factor in achieving higher efficiency of QDSCs [41]. However, the in situ electrochemistry deposition method has been found to be an effective approach to ensure high surface coverage of $\mathrm{TiO}_{2}$ and direct attachment between QDs and $\mathrm{TiO}_{2}$ matrix [42], demonstrating a platform for fabricating high performance solar cells via doping systems.

\section{Conclusions}

In summary, SILAR method was used to fabricate PbS:In QDSCs. A superior short circuit current density up to $23 \mathrm{~mA} \cdot \mathrm{cm}^{-2}$ was achieved in the resulting cells with doped 
QDs, mainly attributed to the separation of electrons and holes and charge transfer improvement. The results demonstrate a promising potential method for fabricating high performance QDSCs.

\section{Conflict of Interests}

The authors declare that there is no conflict of interests regarding the publication of this paper.

\section{Acknowledgments}

This work was partially supported by Key Project of Beijing Natural Science Foundation (3131001), Key Project of Natural Science Foundation of China (91233201 and 61376057), Key Project of Beijing Education Committee Science \& Technology Plan (KZ201211232040), State 863 Plan of MOST of China (2011AA050527), Beijing National Laboratory for Molecular Sciences (BNLMS2012-21), State Key Laboratory of Solid State Microstructures of Nanjing University (M27019), State Key Laboratory for New Ceramic and Fine Processing of Tsinghua University (KF1210), Key Laboratory for Renewable Energy and Gas Hydrate of Chinese Academy of Sciences (y207ka1001), Beijing Key Laboratory for Sensors of BISTU (KF20141077207 and KF20141077208), and Beijing Key Laboratory for photoelectrical measurement of BISTU (GDKF2013005).

\section{References}

[1] A. Braga, S. Giménez, I. Concina, A. Vomiero, and I. MoraSeró, "Panchromatic sensitized solar cells based on metal sulfide quantum dots grown directly on nanostructured $\mathrm{TiO}_{2}$ electrodes," Journal of Physical Chemistry Letters, vol. 2, no. 5, pp. 454-460, 2011.

[2] B. O’Regan and M. Grátzel, "A low-cost, high-efficiency solar cell based on dye-sensitized colloidal $\mathrm{TiO}_{2}$ films," Nature, vol. 353, pp. 737-740, 1991.

[3] F. Hetsch, X. Xu, H. Wang, S. V. Kershaw, and A. L. Rogach, "Semiconductor nanocrystal quantum dots as solar cell components and photosensitizers: material, charge transfer, and separation aspects of some device topologies," The Journal of Physical Chemistry Letters, vol. 2, no. 15, pp. 1879-1887, 2011.

[4] X. Yu, J. Zhu, Y. Zhang, J. Weng, L. Hu, and S. Dai, "SnSe 2 quantum dot sensitized solar cells prepared employing molecular metal chalcogenide as precursors," Chemical Communications, vol. 48, no. 27, pp. 3324-3326, 2012.

[5] Z. Yang, C. Y. Chen, and H. T. Roy, "The abrupt change of electric field breaks the originally established dynamic equilibrium between the $\mathrm{Ti}$ oxidation and dissolution of $\mathrm{TiO}_{2}$," Chemical Communications, vol. 47, pp. 9561-9571, 2011.

[6] L. M. Peter, D. J. Riley, E. J. Tull, and K. G. U. Wijayantha, "Photosensitization of nanocrystalline $\mathrm{TiO}_{2}$ by self-assembled layers of CdS quantum dots," Chemical Communications, no. 10, pp. 1030-1031, 2002.

[7] I. Robel, V. Subramanian, M. Kuno, and P. V. Kamat, "Quantum dot solar cells. Harvesting light energy with CdSe nanocrystals molecularly linked to mesoscopic $\mathrm{TiO}_{2}$ films," Journal of the American Chemical Society, vol. 128, no. 7, pp. 2385-2393, 2006.
[8] R. Plass, P. Serge, J. Krüger, and M. Grátzel, "Quantum dot sensitization of organic-inorganic hybrid solar cells," The Journal of Physical Chemistry B, vol. 106, pp. 7578-7580, 2002.

[9] P. Sudhagar, J. H. Jung, S. Park et al., "The performance of coupled (CdS:CdSe) quantum dot-sensitized $\mathrm{TiO}_{2}$ nanofibrous solar cells," Electrochemistry Communications, vol. 11, no. 11, pp. 2220-2224, 2009.

[10] M. Seol, H. Kim, Y. Tak, and K. Yong, "Novel nanowire array based highly efficient quantum dot sensitized solar cell," Chemical Communications, vol. 46, pp. 5521-5523, 2010.

[11] C. Ratanatawanate, C. Xiong, and K. J. Balkus Jr., "Fabrication of $\mathrm{PbS}$ quantum dot doped $\mathrm{TiO}_{2}$ nanotubes," ACS Nano, vol. 2, no. 8, pp. 1682-1688, 2008.

[12] N. Zhou, G. Chen, X. Zhang et al., "Highly efficient PbS/CdS co-sensitized solar cells based on photoanodes with hierarchical pore distribution," Electrochemistry Communications, vol. 20, no. 1, pp. 97-100, 2012.

[13] B.-R. Hyun, Y.-W. Zhong, A. C. Bartnik et al., "Electron injection from colloidal $\mathrm{PbS}$ quantum dots into titanium dioxide nanoparticles," ACS Nano, vol. 2, no. 11, pp. 2206-2212, 2008.

[14] M. Samadpour, P. P. Boix, S. Giménez et al., "Fluorine treatment of $\mathrm{TiO}_{2}$ for enhancing quantum dot sensitized solar cell performance," Journal of Physical Chemistry C, vol. 115, no. 29, pp. 14400-14407, 2011.

[15] S. Kim, Y. T. Lim, E. G. Soltesz et al., "Near-infrared fluorescent type II quantum dots for sentinel lymph node mapping," Nature Biotechnology, vol. 22, no. 1, pp. 93-97, 2004.

[16] X. Gao, Y. Cui, R. M. Levenson, L. W. K. Chung, and S. Nie, "In vivo cancer targeting and imaging with semiconductor quantum dots," Nature Biotechnology, vol. 22, no. 8, pp. 969976, 2004.

[17] R. G. Xie, K. Chen, X. Y. Chen, and X. Peng, "InAs/InP/ZnSe core/shell/shell quantum dots as near-infrared emitters: bright, narrow-band, non-cadmium containing, and biocompatible," Nano Research, vol. 1, pp. 457-464, 2008.

[18] H. Yang and P. H. Holloway, "Enhanced photoluminescence from CdS:Mn/ZnS core/shell quantum dots," Applied Physics Letters, vol. 82, no. 12, pp. 1965-1967, 2003.

[19] N. Pradhan, D. Goorskey, J. Thessing, and X. Peng, "An alternative of CdSe nanocrystal emitters: pure and tunable impurity emissions in ZnSe nanocrystals," Journal of the American Chemical Society, vol. 127, no. 50, pp. 17586-17587, 2005.

[20] Y. Yang, O. Chen, A. Angerhofer, and Y. C. Cao, "Radialposition-controlled doping in $\mathrm{CdS} / \mathrm{ZnS}$ core/shell nanocrystals," Journal of the American Chemical Society, vol. 128, no. 38, pp. 12428-12429, 2006.

[21] D. J. Norris, A. L. Efros, and S. C. Erwin, "Doped nanocrystals," Science, vol. 319, no. 5871, pp. 1776-1779, 2008.

[22] W. Lee, W.-C. Kwak, S. K. Min et al., "Spectral broadening in quantum dots-sensitized photoelectrochemical solar cells based on CdSe and Mg-doped CdSe nanocrystals," Electrochemistry Communications, vol. 10, no. 11, pp. 1699-1702, 2008.

[23] X. P. Zou, Z. B. Huang, and H. Q. Zhou, "Application of indium doped plumboussulfide quantum dots of quantum dot sensitized solar cells and the preparation methods of the doped quantum dots, China," Patent 201210520527.8, 2012.

[24] S. Jana, B. B. Srivastava, and N. Pradhan, "Correlation of dopant states and host bandgap in dual-doped semiconductor nanocrystals," The Journal of Physical Chemistry Letters, vol. 2, no. 14, pp. 1747-1752, 2011. 
[25] R. G. Xie and X. G. Peng, "Synthesis of Cu-doped InP nanocrystals (d-dots) with ZnSe diffusion barrier as efficient and colortunable NIR emitters," Journal of the American Chemical Society, vol. 131, no. 30, pp. 10645-10651, 2009.

[26] J. W. Lee, D. Y. Son, T. K. Ahn et al., "Quantum dot sensitized solar cell with unprecedentedly high photocurrent," Scientific Reports, vol. 3, pp. 1050-1058, 2013.

[27] K. Prabakar, H. Seo, M. Son, and H. Kim, "CdS quantum dots sensitized $\mathrm{TiO}_{2}$ photoelectrodes," Materials Chemistry and Physics, vol. 117, no. 1, pp. 26-28, 2009.

[28] Z. B. Huang, X. P. Zou, and H. Q. Zhou, "A strategy to achieve superior photocurrent by $\mathrm{Cu}$-doped quantum dot sensitized solar cells," Materials Letters, vol. 95, pp. 139-141, 2013.

[29] Y.-L. Lee and Y.-S. Lo, "Highly efficient quantum-dot-sensitized solar cell based on co-sensitization of CdS/CdSe," Advanced Functional Materials, vol. 19, no. 4, pp. 604-609, 2009.

[30] H. J. Lee, H. C. Leventis, S. J. Moon et al., "PbS and CdS quantum dot-sensitized solid-state solar cells: "Old Concepts, New Results'”' Advanced Functional Materials, vol. 19, no. 17, pp. 2735-2742, 2009.

[31] G. Hodes, "Chemical bath deposited CdS/CdSe-sensitized porous $\mathrm{TiO}_{2}$ solar cells," The Journal of Physical Chemistry C, vol. 112, no. 46, pp. 17778-17787, 2008.

[32] F. Zhou, K. Kang, T. Maxisch, G. Ceder, and D. Morgan, "The electronic structure and band gap of $\mathrm{LiFePO}_{4}$ and $\mathrm{LiMnPO}_{4}$," Solid State Communications, vol. 132, no. 3-4, pp. 181-186, 2004.

[33] P. Ardalan, T. P. Brennan, H.-B. Lee et al., "Effects of selfassembled monolayers on solid-state CdS quantum dot sensitized solar cells," ACS Nano, vol. 5, no. 2, pp. 1495-1504, 2011.

[34] L. Li, X. Yang, J. Gao et al., "Highly efficient CdS quantum dot-sensitized solar cells based on a modified polysulfide electrolyte," Journal of the American Chemical Society, vol. 133, no. 22, pp. 8458-8460, 2011.

[35] G. Zhu, L. Pan, T. Xu, and Z. Sun, "CdS/CdSe-cosensitized $\mathrm{TiO}_{2}$ photoanode for quantum-dot-sensitized solar cells by a microwave-assisted chemical bath deposition method," ACS Applied Materials and Interfaces, vol. 3, no. 8, pp. 3146-3151, 2011.

[36] S. W. Watson, "Electrochemical study of SiC particle occlusion during nickel $100 \mathrm{~nm}$ wide copper lines made by selective electroless deposition," Journal of the Electrochemical Society, vol. 140, pp. 2229-2235, 1993.

[37] G. Zhu, L. K. Pan, T. Xu, and Z. Sun, "One-step synthesis of CdS sensitized $\mathrm{TiO}_{2}$ photoanodes for quantum dot-sensitized solar cells by microwave assisted chemical bath deposition method," ACS Applied Materials and Interfaces, vol. 3, no. 5, pp. 1472-1478, 2011.

[38] I. Mora-Seró, S. Giménez, F. Fabregat-Santiago, R. Gómez, Q. Shen, and T. Toyoda, "Recombination in quantum dot sensitized solar cells," Accounts of Chemical Research, vol. 42, no. 11, pp. 1848-1857, 2009.

[39] V. González-Pedro, X. Xu, I. Mora-Seró, and J. Bisquert, "Modeling high-efficiency quantum dot sensitized solar cells," ACS Nano, vol. 4, no. 10, pp. 5783-5790, 2010.

[40] J. G. Radich, R. Dwyer, and P. V. Kamat, " $\mathrm{Cu}_{2} \mathrm{~S}$ reduced graphene oxide composite for high-efficiency quantum dot solar cells. Overcoming the redox limitations of $S_{2}{ }^{-} / S_{2}{ }^{2-}$ at the counter electrode," Journal of Physical Chemistry Letters, vol. 2, no. 19, pp. 2453-2460, 2011.

[41] V. Chakrapani, D. Baker, and P. V. Kamat, "Understanding the role of the sulfide redox couple $\left(S^{2-} / S_{n}{ }^{2-}\right)$ in quantum dotsensitized solar cells," Journal of the American Chemical Society, vol. 133, no. 24, pp. 9607-9615, 2011.
[42] X.-Y. Yu, J.-Y. Liao, K.-Q. Qiu, D.-B. Kuang, and C.-Y. Su, "Dynamic study of highly efficient CdS/CdSe quantum dotsensitized solar cells fabricated by electrodeposition," ACS Nano, vol. 5, no. 12, pp. 9494-9500, 2011. 

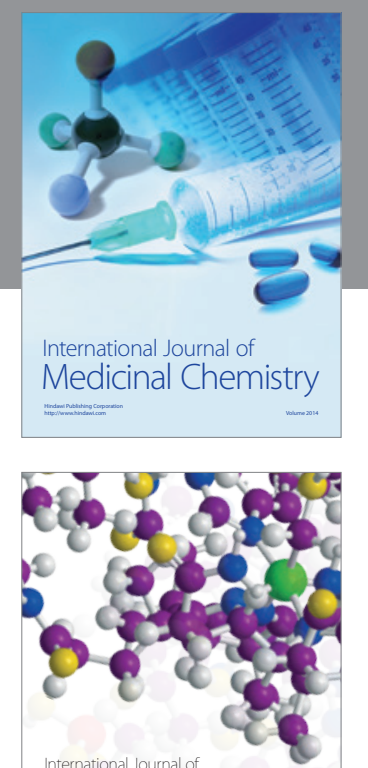

\section{Carbohydrate} Chemistry

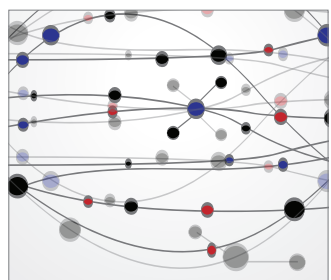

The Scientific World Journal
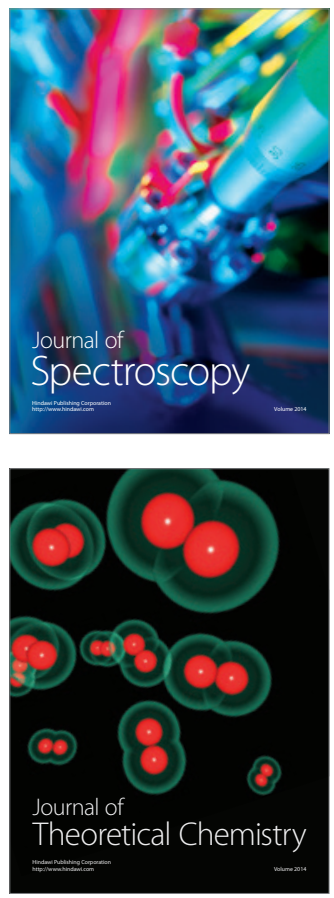
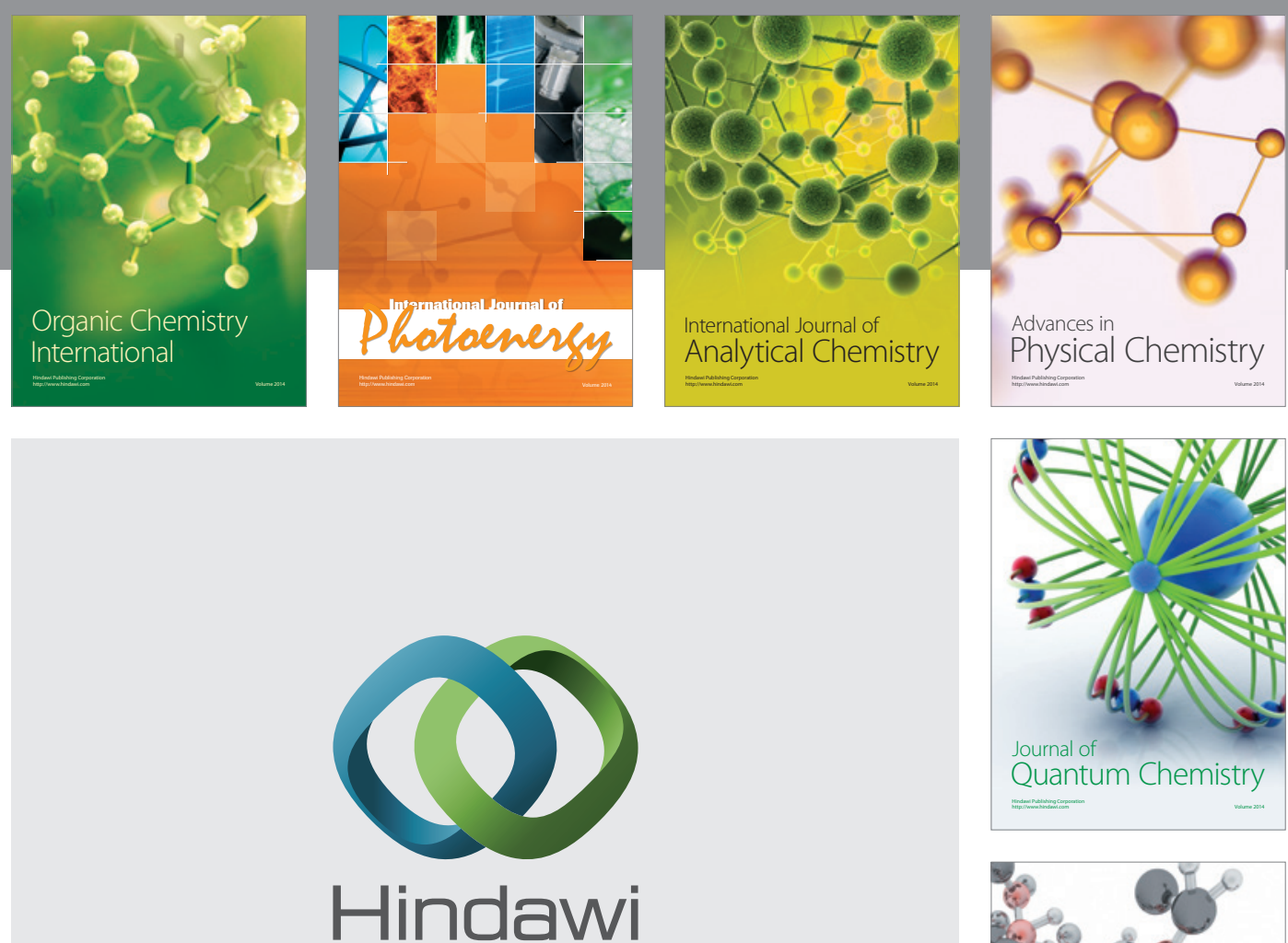

Submit your manuscripts at

http://www.hindawi.com

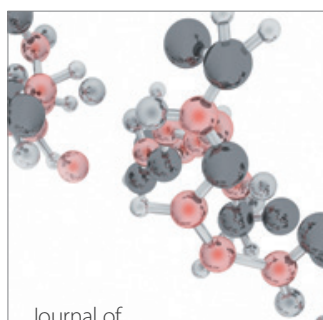

Analytical Methods

in Chemistry

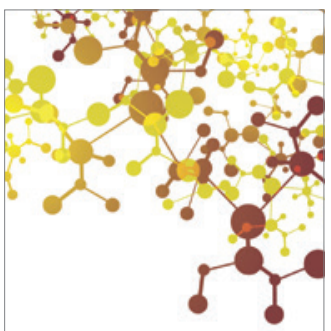

Journal of

Applied Chemistry

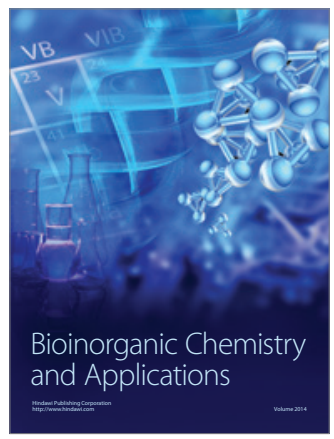

Inorganic Chemistry
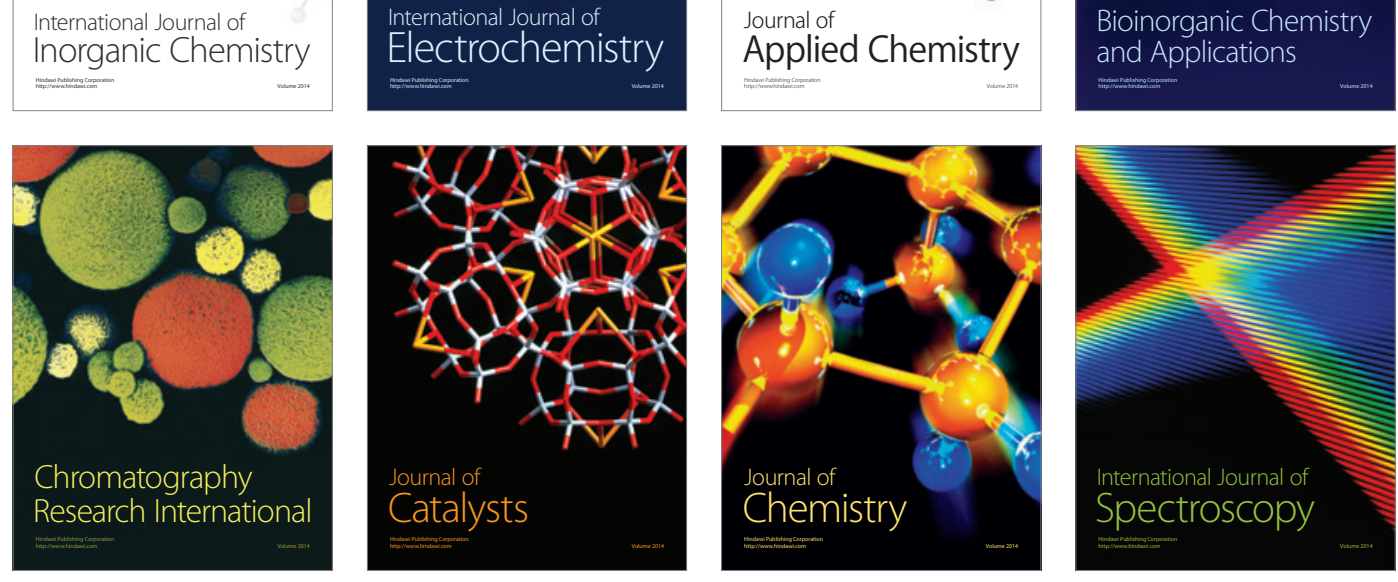